\title{
Effect of Season, Location, Filleting Regime and Storage on Water-Holding Properties of Farmed Atlantic Salmon (Salmo salar L.)
}

\section{Bjørn Tore Rotabakk**, Gaute Lunde Melberg² and Jørgen Lerfall ${ }^{3}$}

'Nofima AS, Department of Processing Technology, P.O. Box 327, NO-4002 Stavanger, Norway

${ }^{2}$ Marine Harvest AS, Department of Quality and Environment Region South, P.O. Box 4102 Sandviken, NO-5835 Bergen, Norway ${ }^{3}$ Department of Biotechnology and Food Science, Norwegian University of Science and Technology, NO-7491 Trondheim, Norway

Received: 16 May 2017 Accepted: 17 November 2017

\author{
${ }^{*}$ Corresponding author: \\ Phone: +4777629000; \\ E-mail: bjorn.tore.rotabakk@nofima.no
}

ORCID IDs: 0000-0002-1170-1668 (Rotabakk), 0000-0002-9855-3361 (Melberg), 0000-0001-6243-0880 (Lerfall)

\begin{abstract}
SUMMARY
The effect of season, localization, filleting regime and storage on water-holding properties of Atlantic salmon (Salmo salar L.) was investigated. Salmon was sampled at two different slaughter facilities (in the north and south of Norway) in autumn and spring and divided in pre- and post-rigor groups, which were sampled before and after filleting. This gave a total of 16 groups that were analyzed for water-holding capacity (WHC), water content and $\mathrm{pH}$. In addition, a storage trial was performed to assess the effect of all the design variables on drip loss and the composition of the drip loss during up to 18 days of storage. WHC was significantly affected by both rigor status and filleting, while water content was affected by localization and filleting. In addition, post-rigor filleting gave significantly decreased drip loss compared to pre-rigor filleting. However, storage time had the highest impact on the drip loss. Based on this, it is concluded that pre-rigor filleted salmon have excellent water-holding properties and a great potential for early processing (pre-rigor processing). It was however difficult to find a clear connection between the drip loss and the water-holding capacity of the muscle.
\end{abstract}

Key words: Atlantic salmon, water-holding capacity, drip loss, rigor mortis

\section{INTRODUCTION}

Atlantic salmon (Salmo salar L.) is highly valuable species for the Norwegian aquaculture. Norway produced 980000 metric tonnes of Atlantic salmon with an export value of 61.4 billion Norwegian krones (approx. $€ 6.63$ billion) in 2016. Drip loss and the ability of the salmon muscle to retain water during primary processing and ice storage are important factors that affect both consumer perception and the profitability for the producer (1-3). Most of the water in muscle tissue is kept within the structure of the muscle and muscle cells (4). Within the muscle cell, water is found inside the myofibrils, between the myofibrils themselves and between the myofibrils and the sarcolemma (cell membrane), between muscle cells and between groups of muscle cells (5). Water is moreover bound to proteins by hydrogen bonds, where the capacity of the specific protein depends on the net surface charge (affected by $\mathrm{pH}$ ) and the polarity of the specific proteins.

Drip loss from muscle foods occurs due to changed capacity of the muscle structure to retain its natural water $(2,4)$ and is closely related to the water-holding capacity (WHC) of the flesh. WHC of Atlantic salmon is known to be affected by several pre-and post mortem factors including stress prior to slaughtering $(6,7)$, starvation (8), and state of rigor mortis $(9,10)$. The WHC is also known to be affected by $\mathrm{pH}$, because $\mathrm{pH}$ close to the isoelectric point is known to lower the WHC (4). The drip loss from salmon fillets consists mainly of water, proteins and lipids, and is affected by a drop in muscle $\mathrm{pH}$ due to anaerobic glycolysis (9) and ultrastructural changes during rigor mortis (10). A rapid drop of $\mathrm{pH}$ can, in all likelihood, also lead to denaturation of muscle and sarcoplasmic proteins. During ice storage, however, Hultmann and Rustad (11) indicated that WHC in salmon muscle seems to be unrelated to muscle $\mathrm{pH}$ due to small variations in $\mathrm{pH}$ during storage of post-rigor fillets. 
Previous research has pointed to the fact that seasonal variations influence the drip loss. A study with pre-rigor filleted Atlantic salmon, stored for 13 days at $4{ }^{\circ} \mathrm{C}$, observed the highest drip loss in October and the lowest drip loss in April (12). In addition, the Norwegian salmon industry has observed differences in water-holding properties of salmon fillets related to a north-south gradient along the Norwegian coast. In addition, a relatively high drip loss has been observed in pre-rigor filleted salmon during the first days when exported in ice $\left(0^{\circ} \mathrm{C}\right)$.

Even though considerable work has been done in the last few years to describe the WHC of muscle foods, little if any work has been done to study WHC of Atlantic salmon muscle in pre-rigor state. In the presented study, we studied the WHC of both pre- and post-rigor muscle from whole head on gutted (HOG), and pre- and post-rigor muscle from fillets of Atlantic salmon. The study was moreover performed at two different localities in a north-south gradient along the Norwegian coast, both in spring and in autumn. The aim of the study is to gain more knowledge about factors affecting WHC and water content of Atlantic salmon fillets, and subsequently the drip loss during storage. Investigated factors were: season, Norwegian coast (north and south), filleting (whole fish versus fillets) and time of filleting (pre-versus post-rigor).

\section{MATERIAL AND METHODS}

\section{Experimental animals and design}

In May 2013, November 2013 and May 2014, a total of 160 farmed Atlantic salmon (Salmo salar) with mean value \pm standard deviation (S.D.) mass of (4.4 \pm 1.2$) \mathrm{kg}$ were sampled during commercial slaughtering at two different plants in Norway. A full factorial design (Fig. 1) with four factors was designed; season (spring/autumn), location (north/south), rigor status (pre/post) and filleting (HOG/fillet) resulting in 16 different groups where
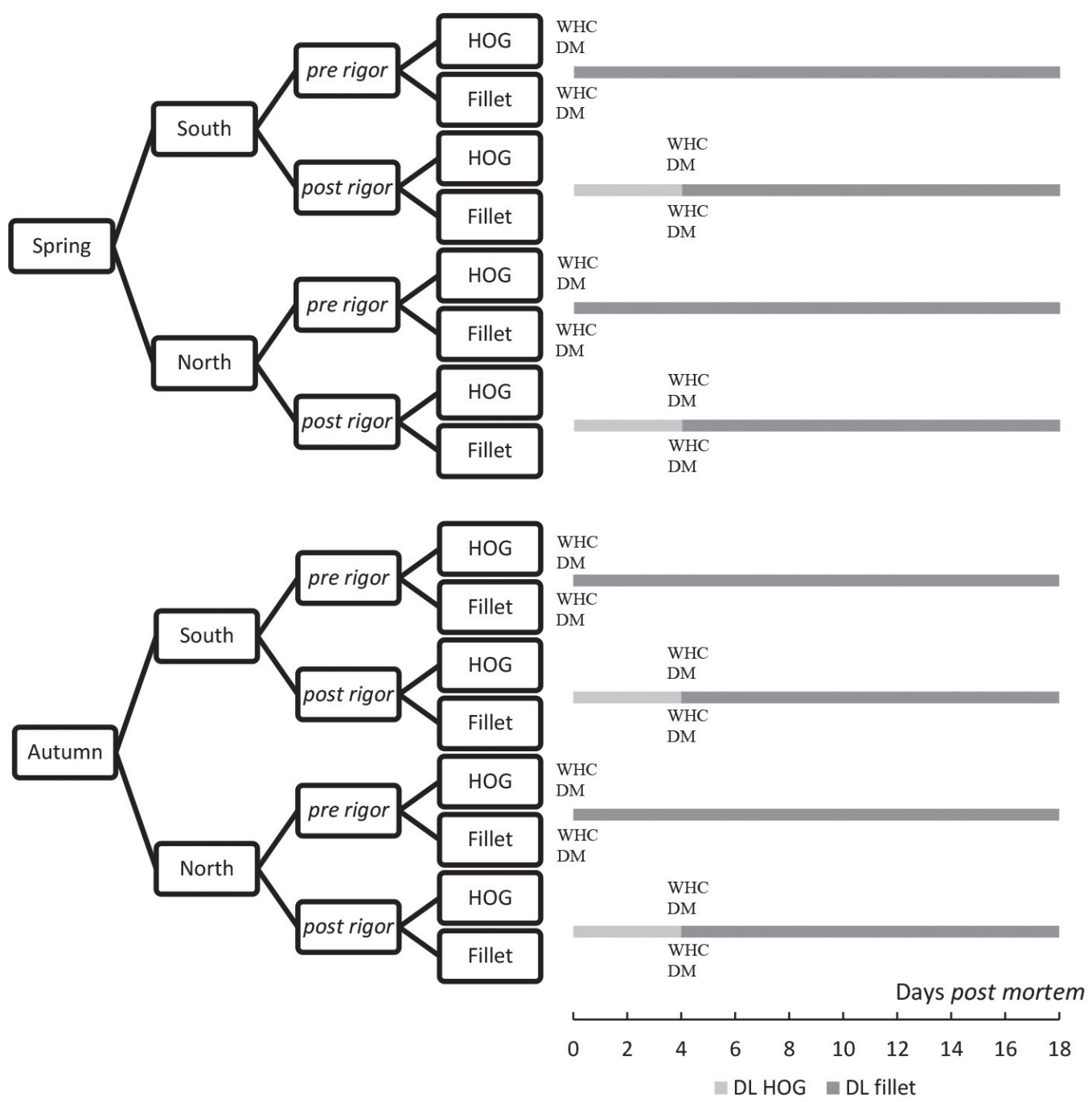

Fig. 1. Schematic illustration of the experimental design, where spring and autumn refer to May and November, respectively, south and north to $\mathrm{N} 58-59^{\circ}$ and $\mathrm{N} 63-64^{\circ}$, respectively, pre- and post-rigor to point of filleting, and head on gutted (HOG) and fillet to when the analysis was conducted (before and after filleting, respectively). The time scale shows when the specific analyses were conducted for each group. WHC=water-holding capacity, $\mathrm{DM}=$ dry matter, $\mathrm{DL}=$ drip loss 
the effect on water-holding capacity (WHC) and water content was investigated. In addition, 160 fillets with mean \pm S.D. mass of $(1.6 \pm 0.4) \mathrm{kg}$ from the entire design apart from the filleting were stored on ice for 14 days to quantify the drip loss during storage and to determine the composition of the drip loss (Fig. 1).

Fish from the north site was farmed around N63-64 ${ }^{\circ}$ while the fish from the south site was farmed around N58$59^{\circ}$ along the west coast of Norway. Spring part of the trial was performed in May, while the autumn part was performed in November. The sea temperature was 9.5 and $5.0{ }^{\circ} \mathrm{C}$ at the south location, while the north location had 9.5 and $6.0^{\circ} \mathrm{C}$ in November and May, respectively. Before sampling, the fish were slaughtered according to the commercial practice at the plants; the fish was crowded, pumped in a double-chamber vacuum pump, live chilled up to $45 \mathrm{~min}$, stunned with percussive captive bolt and gills were cut before bleeding in a bleeding tank for up to $60 \mathrm{~min}$. The fishes were then gutted to end up as head on gutted (HOG), and all the fish were measured (mass, length and $\mathrm{pH}$ ), tagged and randomly subjected to pre- or post-rigor analysis and WHC or storage trial, respectively. The fish subjected to pre-rigor analysis were analyzed consecutively, while fish subjected to post-rigor analysis were stored in expanded polystyrene boxes on ice in a chilled room $\left(0-4{ }^{\circ} \mathrm{C}\right)$ for four days to go through rigor mortis.

\section{$\mathrm{pH}$, temperature, condition factor and drip loss}

$\mathrm{pH}$ and temperature were measured right after gutting in the anterior dorsal muscle close to the gills, using a Mettler Toledo SevenGo Pro ${ }^{\mathrm{TM}}$ pH-meter (Mettler Toledo Inc., Columbus, $\mathrm{OH}$, USA) connected to an Inlab puncture electrode (ibid). In addition, post-rigor fish were measured after 4 days of storage. During storage of fillets, muscle $\mathrm{pH}$ and temperature were measured on the cranial part of the fillet.

Before analysis, the fish were dried off and weighed, and the fork length was measured. Fulton's condition factor (CF) (13) was calculated for gutted fish according to the following formula:

$$
\mathrm{CF}=m / \beta^{3} \cdot 0.1
$$

where $m$ is gutted mass $(\mathrm{kg})$ and $/$ is fork length $(\mathrm{m})$.

In the storage trial, HOG subjected to post-rigor filleting were weighed after being dried off on day 0 and day 4 to quantify the drip loss. Fillets for the storage trial were machine filleted, dried off, weighed and packaged in a closed bulk polyethylene bag inside expanded polystyrene boxes with top icing. Thereafter, all samples were transported within $24 \mathrm{~h}$ to the laboratory where the fillets were stored in chilled rooms $\left(0-4^{\circ} \mathrm{C}\right)$ for 14 days. During storage, melting water was removed through weep holes in the bottom of each box, while drip loss was gathered. Drip loss (DL/\%) from the fillets was measured as the difference in fillet mass between day 0 and day $x$ of both the right and left fillet:

$$
\mathrm{DL}=\left(\frac{m_{0}-m_{\mathrm{x}}}{m_{0}}\right) \cdot 100
$$

where $m_{0}$ is fillet mass ( $\mathrm{g}$ ) on day 0 , and $m_{\mathrm{x}}$ is fillet mass ( $\mathrm{g}$ ) on day $\mathrm{x}$.

Drip loss was assessed on days 7 and 14 after filleting (i.e. day 7 and 14 for pre-rigor, and day 4 (HOG), day 11 and 18 for post-rigor). In addition, drip loss of post-rigor fillets is reported as cumulated drip loss including drip loss as HOG. An average of both fillets was used for statistical analysis.

\section{Water-holding capacity and water content}

Water-holding capacity was measured in the dorsal muscle. Samples for determination of WHC and water content of whole fish were first sampled from the left side before the fish was machine filleted, and samples from the right fillet were taken approx. 45 min later. Samples were cut in triplicates (diameter $31 \mathrm{~mm}$, hight $20 \mathrm{~mm}$ ) from the cranial part on the dorsal back and backwards, above the lateral line on identical locations on all fishes using the white muscle tissue (Fig. 2). Three portions from each sample, approx. $5 \mathrm{~g}$ were made, and the first two (Fig. 2c, I and II) were weighed and dried at $105^{\circ} \mathrm{C}$ for 16 to $24 \mathrm{~h} \mathrm{(14)}$ for estimating the dry content of the muscle and hence the water content. The last sample (Fig. 2c, III) was weighed and placed into metal carriers (Hettich Lab Technology, Tuttlingen, Germany) and centrifuged (Rotina $420 \mathrm{R}$; Hettich Lab Technology) for $15 \mathrm{~min}$ at $4{ }^{\circ} \mathrm{C}$, using a free swing rotor at $530 \times g$. WHC was calculated from the following formula (15):

$$
\mathrm{WHC}=\left(\frac{w-\Delta w}{w}\right) \cdot 100
$$

where

$$
w=\left(\frac{m_{w}}{\left(m_{w}+m_{D}\right)}\right) \cdot 100
$$

and

$$
\Delta w=\left(\frac{\Delta m_{\mathrm{w}}}{\left(m_{\mathrm{w}}+m_{\mathrm{D}}\right)}\right) \cdot 100
$$

where $m_{\mathrm{w}}$ is the mass $(\mathrm{g})$ of water in the muscle sample, $m_{\mathrm{D}}$ is the mass ( $\mathrm{g}$ ) of dry matter in the muscle sample, and $\Delta m_{\mathrm{w}}$ is the mass of the liquid separated from the sample during centrifugation.

\section{Composition of drip loss}

During storage, the fillets were stored in closed bags to gather the drip loss and to prevent contamination from the melting ice. The amount of water, protein, fat and astaxanthin were quantified in triplicate according to the design.

Nitrogen content was measured on a Tecator Kjeltec system (model 2020 digestor and 1026 distilling unit; Tecator, Höganäs, Sweden) (16). Protein content was calculated from nitrogen measurements using the formula:

$$
w(\text { protein })=w(\text { nitrogen }) \cdot 6.25
$$




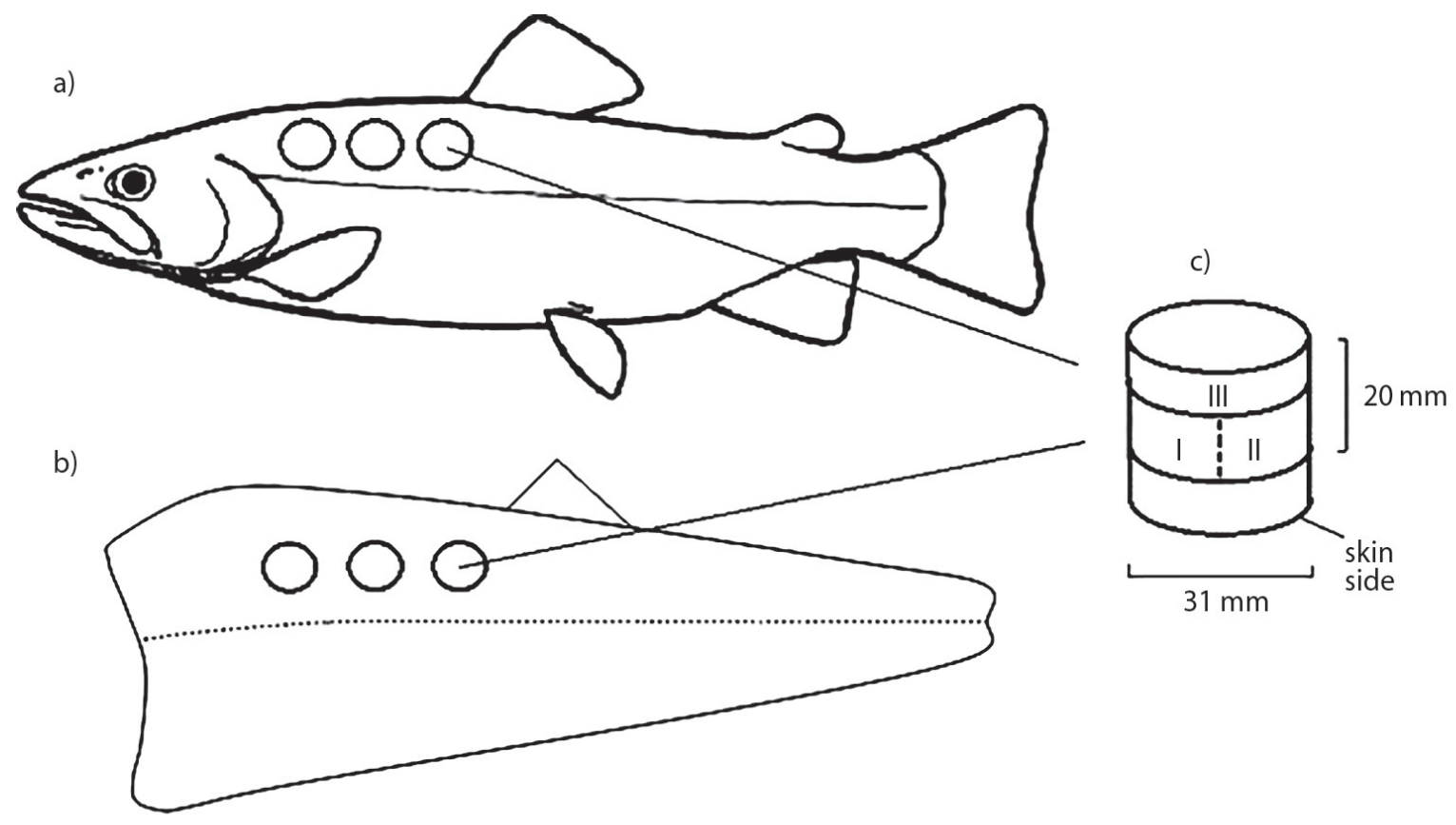

Fig. 2. Schematic illustration of the: a) head on gutted and b) fillet areas used for determination of water-holding capacity (WHC) and water content (WC). In addition, insert c) shows the splitting and use of the sample, where two parts were used for WC (I and II) and one part for WHC (III) determination

Fat and astaxanthin were extracted by a method after Bligh and Dyer (17). Total contents of fat were calculated and total contents of astaxanthin were quantified by HPLC using $\mathrm{a}_{3} \mathrm{PO}_{4}$-modified silica gel column (17) and all-E-astaxanthin (A-9335; Sigma-Aldrich, Merck, St. Louis, MO, USA) as an external standard. The eluent was acetone/ $n$-hexane (86:14) and the flow was $1.2 \mathrm{~mL} / \mathrm{min}$. Detection wavelength was set at 470 $\mathrm{nm}$. The employed molar absorption coefficients, $\varepsilon_{1 \mathrm{~cm}}(1 \%)$, at $470 \mathrm{~nm}$ in hexane containing $4 \%$ (by volume) $\mathrm{CHCl}_{3}$ were 2100 for all-E-astaxanthin (18), and 1350 and 1750 for 13Zand 9Z-astaxanthin, respectively. The $\varepsilon_{1 \mathrm{~cm}}(1 \%)$ for 13Z- and 9Z-astaxanthin were estimated from the HPLC response factors of Schüep and Schierle (19). Water content was measured as described previously.

\section{Statistics}

All data were analyzed by general linear model (GLM), regression ( $R$ ) and Pearson's correlation coefficient ( $r$ ), using Minitab v. 17 statistical software (20). All results are given as mean value \pm S.D., unless stated otherwise.

\section{RESULTS AND DISCUSSION}

\section{Biometrics}

Comparing different populations of fish during commercial conditions certainly poses many challenges, as the fish used in this trial was sampled during a period of one year at two different locations. Even if they differed significantly $(p<0.002)$ in gutted mass between the two locations (north
$(4.1 \pm 1.1) \mathrm{kg}$, south $(4.7 \pm 1.2) \mathrm{kg})$, none of the design factors varied significantly in initial $\mathrm{pH}(\mathrm{p}>0.084)$ or condition factor $(p>0.065)$. Average initial $\mathrm{pH}$ was $6.9 \pm 0.3$, while condition factor was $1.1 \pm 0.1$.

\section{Water-holding capacity, water content and $\mathrm{pH}$}

Water-holding capacity is known to be related to $\mathrm{pH}$, but including $\mathrm{pH}$ as a covariate in the general linear model did not give any significant result $(p=0.645)$. The WHC was measured at three different positions on the fillet (Fig. 2), but no effect of position on the fillet ( $p=0.295$ ) was detected, so the average of the three measurements was used in the following analysis of the results.

The water content in the muscle was not affected by season, but there was a significant difference between the two localizations ( $p<0.001, F=14)$ (Table 1), and a significant $(p<0.001, F=147)$ interaction between localization and season was detected (Fig. 3). In addition, $\mathrm{pH}$ was significantly affected by localization $(p<0.001, F=78)$ and season $(p=0.001, F=12)$ (Table 1) together with an interaction effect between localization and rigor ( $\mathrm{p}<0.001, \mathrm{~F}=29$, data not shown). No other significant ( $p>0.190)$ effects on $\mathrm{pH}$ were detected.

Furthermore, a significant difference $(p<0.001, F=148)$ between HOG and fillet was detected in WHC (Table 1), where fillet had a decrease of $2.6 \%$ compared to HOG. The water content in the muscle was significantly affected by filleting $(p<0.001, F=78)$, where HOG had approx. $2 \%$ more water than the fillet, measured on the same fish. Filleting opens up the muscle structure of the fish and removes amongst other the 
Table 1. Effect of rigor status (pre/post), filleting (fillet/head on gutted (HOG)), season (spring/autumn) and localization (north/south) on water-holding capacity (WHC), water content and $\mathrm{pH}$ of the muscle of Atlantic salmon (Salmo salar)

\begin{tabular}{lccc} 
& WHC/\% & $w($ water $) / \%$ & $\mathrm{pH}$ \\
Rigor $(N=80)$ & & & \\
Pre & $95.8 \pm 2.2$ & $64.8 \pm 3.0$ & $6.9 \pm 0.3$ \\
Post & $90.4 \pm 3.2$ & $64.9 \pm 3.3$ & $6.29 \pm 0.06$ \\
p-value & $<0.001$ & $>0.05$ & $<0.001$ \\
Filleting $(N=80)$ & & & \\
HOG & $94.4 \pm 3.7$ & $65.9 \pm 3.0$ & $6.6 \pm 0.4$ \\
Fillet & $91.8 \pm 3.6$ & $63.8 \pm 3.0$ & $6.6 \pm 0.4$ \\
p-value & $<0.001$ & $<0.001$ & $>0.05$ \\
Season $(N=80)$ & & & \\
Spring & $93.0 \pm 3.8$ & $64.7 \pm 3.6$ & $6.6 \pm 0.4$ \\
Autumn & $93.2 \pm 4.0$ & $65.9 \pm 2.7$ & $6.6 \pm 0.4$ \\
p-value & $>0.05$ & $>0.05$ & $<0.001$ \\
Localization $(N=80)$ & & & \\
South & $93.2 \pm 3.93$ & $65.3 \pm 3.1$ & $6.7 \pm 0.4$ \\
North & $93.0 \pm 3.85$ & $64.4 \pm 3.2$ & $6.5 \pm 0.3$ \\
p-value & $>0.05$ & $<0.001$ & $<0.001$ \\
\hline
\end{tabular}

The results are expressed as mean value \pm S.D., ranked by ANOVA (general linear model)

peritoneum. In addition, it is likely that the filleting machine induces micro-ruptures in the muscle structure. These expose the mucle and physically decrease its water-holding property and the water content. Jørpeland et al. (21) found the same effect in farmed cod, where whole fish had $0.5 \%$ more water than hand-filleted cod. Filleting by machine as done in the present study might give the muscle increased pressure compared to hand filleting. This can have squeezed more water out of the fillet, hence the increased difference than that observed in farmed cod.

Rigor status had a significant $(\mathrm{p}<0.001)$ impact on WHC, with a decrease of $5.5 \%$ on average from pre- to post-rigor, and explained a major part of the observed variation $(F=656)$
(Table 1). No effect of rigor was detected ( $p>0.234$ ) on the water content of the muscle. Assessing WHC of pre-rigor Atlantic salmon has as far as we know never been done before. Several papers report WHC of pre-rigor filleted salmon, but the time of measurement was at least 1 day after filleting $(22,23)$. However, a study of ground rainbow trout (Oncorhynchus mykiss gairdneri) did not reveal any differences in WHC measured immediately or $24 \mathrm{~h}$ post mortem (24). The observed decrease in WHC may be caused by several mechanisms related to the development of rigor mortis. WHC is known to be affected by $\mathrm{pH}$, as $\mathrm{pH}$ close to the isoelectric point is known to lower the WHC (4), while some other researchers have stated that there is no strong connection between the $\mathrm{pH}$ and $\mathrm{WHC}$ in salmon muscle due to small variations during storage (11). Even though $\mathrm{pH}$ was not detected as a covariate to WHC, a positive correlation between $\mathrm{pH}$ and $\mathrm{WHC}$ was found $(\mathrm{r}=0.66$, $\mathrm{p}>0.001)$. This connection was most obvious when comparing pre-vs. post-rigor fish, as both $\mathrm{pH}(\mathrm{p}<0.001, \mathrm{~F}=1589)$ and WHC were significantly decreased in post-rigor fish compared to pre-rigor. $\mathrm{pH}$ had an average drop of approx. $0.6 \mathrm{pH}$ units from pre- to post-rigor, ending up at $\mathrm{pH}=6.29$. This drop is caused by the conversion of glycogen to lactate post mortem (25). In addition, the muscles form actomyosin during rigor, leaving less space for water (26), and together with changes in the salt ion balance (27), these factors might explain the observed drop in WHC between pre-and post-rigor samples.

Higher water content in the muscle implies more loosely bound water that is easier to remove, hence lower WHC and increased drip loss. Both WHC and water content have a significant interaction between localization and season in this trial, where increased amount of water in the muscle was accompanied by decrease in WHC. Water content and fat content are proved to have a strong negative correlation in salmon (28), so the observed difference in water content might imply increased fat content in the fish and that the amount of fat in the fish affects both WHC and drip loss, which might a)

\section{Interaction plot for WHC}

Data mean value

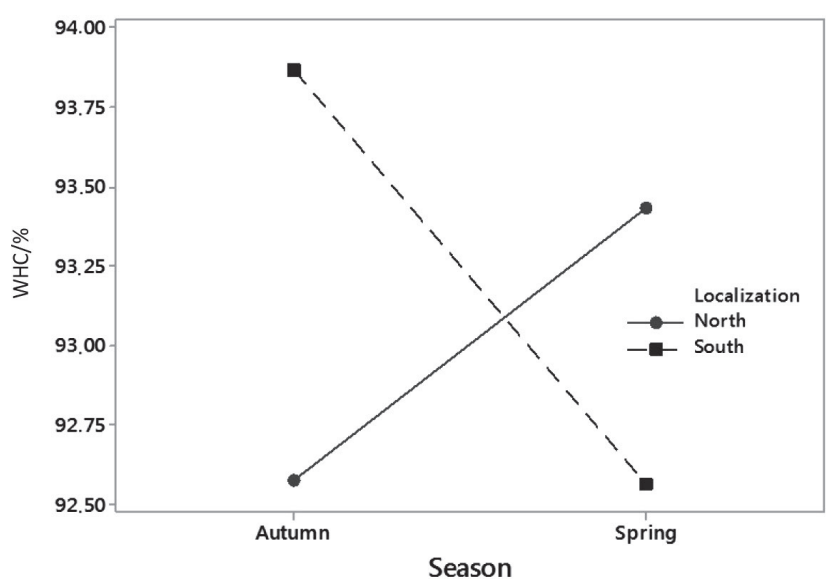

b)

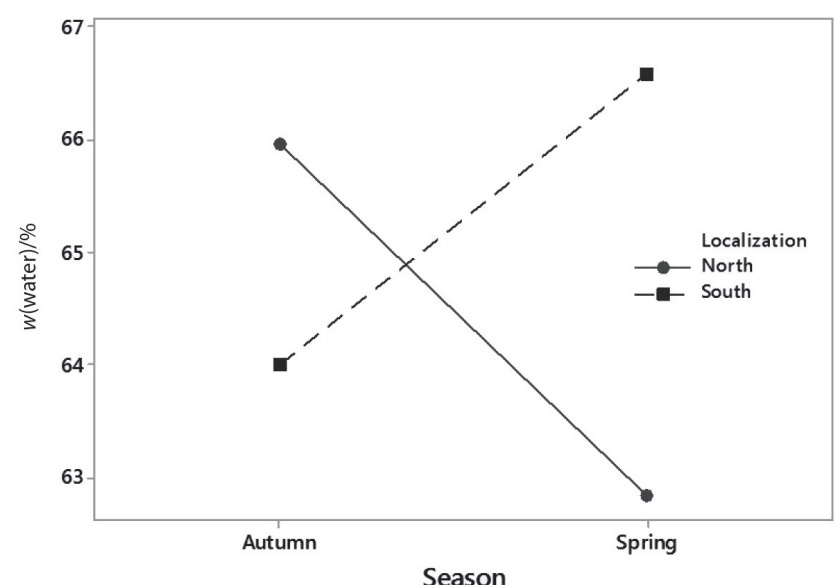

Fig. 3. Interaction plot between localization (north: N63-64, and south: N58-59 ${ }^{\circ}$ ) and season (spring and autumn) for: a) water-holding capacity (WHC; $p<0.001, F=24)$ and $b)$ water content in the muscle $(p<0.001, F=147)(N=80)$ 
explain the observed differences of $\mathrm{WHC}$ and $\mathrm{pH}$ during the season. Observed differences in $\mathrm{pH}$ between the two localities might be explained by stress before slaughter.

\section{Drip loss during storage}

Storage time is a continuous variable and $\mathrm{pH}$ is known to have an influence on water-holding capacity (4), so incorporating both storage time (days from slaughtering) and $\mathrm{pH}$ as covariates into general linear model revealed increased drip loss with both increasing storage time $(r=0.846, p<0.001$, $\mathrm{F}=877)$ and increasing $\mathrm{pH}(\mathrm{r}=0.222, \mathrm{p}<0.001, \mathrm{~F}=14)$.

Season affected the drip loss significantly $(p<0.001, F=16)$ (Table 2). Significant interactions between localization and season ( $p<0.001, F=22$, data not shown) and localization and rigor ( $\mathrm{p}=0.027, \mathrm{~F}=5$, data not shown) were detected. No other significant effects were detected $(p>0.169)$. Season is known to affect both quality and composition of salmon, where fat, texture and drip loss increase after the strong growth in the summer $(12,29)$. The growth of farmed salmon is strongly linked to the temperature of the sea (30), where the fish increase growth up to a certain point, before it drops (31). Both photoperiod and water temperature are different along the long Norwegian coast, where the south part has higher water temperature than the north, but north has longer daylight in the summer. Salmon slaughtered in the spring had $0.27 \%$ increased drip loss compared to those slaughtered in the autumn, while localization had no significant effect ( $p>0.05$ ) on either drip loss or WHC in our trial. In addition, WHC, drip loss and water content had a significant interaction with localization and season, where increased WHC was accompanied by decreased drip loss and decreased water content and vice versa. This is in contradiction with the findings of Mørkøre et al. (12), who found an increased drip loss in October compared to April in salmon, while Roth et al. (32) found no effect of season on turbot.

The drip loss was moreover significantly affected by the rigor status ( $\mathrm{p}<0.001, \mathrm{~F}=49$ ) (Table 2). By splitting the data set in post-rigor and pre-rigor and performing a linear regression with time (Fig. 4), the drip loss of post-rigor fillets increased on average $0.14 \%$ each day $\left(R^{2}=0.945\right)$, whereas the drip loss of pre-rigor fillets increased on average $0.18 \%$ each day $\left(R^{2}=0.985\right)$, reaching $(2.50 \pm 0.46) \%$ on day 18 and $(2.62 \pm 0.50) \%$ on day 14 respectively. The drip loss of HOG after 4 days of storage was $(0.14 \pm 0.34) \%$. Previous studies on the effect of rigor status during filleting on drip loss are inconclusive. Skjervold et al. (33) and Rosnes et al. (34) found higher drip loss in pre-rigor fillets after 14 and 16 days of storage on ice than in post-rigor fillets, while Einen et al. (25) and Skjervold et al. (22) found no effect of filleting time on drip loss. Fillets in the present study had a drip loss of $2.5-2.6 \%$ at the end of storage, while in the cited studies it ranged from $0.9-3 \%$. All these reports related the drip loss to the time from filleting, not the time from slaughtering. In the present study, however, the HOG had almost ignorable drip loss, where some of the HOG even gained mass. One could expect less drip loss in pre-rigor filleted fillets since pre-rigor fillets have higher WHC. The drip loss was however higher in pre-rigor filleted samples than in those filleted post rigor. During filleting the muscle is exposed, which increases the flesh surface and subsequently the potential for drip loss. In addition, WHC in pre-rigor filleted salmon measured post rigor showed the same WHC as post-rigor filleted salmon $(22,23)$. It is important to remember that the major variation of drip loss in the present study was explained by storage time. If the drip loss in the present study was related to the time of filleting, post-rigor would have $0.18 \%$ drip loss on average each day, almost identical to pre-rigor (data not shown).

\section{Composition of drip loss}

Storage time was a significant $(p<0.001)$ covariate for all the four analyzed constituents, where the amount of water $(r=-0.94, p>0.001, F=271)$, fat $(r=-0.85, p>0.001, F=92)$ and astaxanthin $(r=-0.68, p<0.001, F=27)$ decreased significantly with storage time (Table 2). Protein, on the other hand, increased with storage time $(r=0.91, p<0.001, F=205)$.

Table 2. The effect of rigor status during filleting (pre/post-rigor), growth season (spring/autumn) and location (south/north) on drip loss and the composition of drip loss

\begin{tabular}{|c|c|c|c|c|c|}
\hline & \multicolumn{5}{|c|}{ Composition of drip loss } \\
\hline & Drip loss/\% & $w($ water $) / \%$ & $w($ fat $) / \%$ & $w($ protein) $/ \%$ & $\gamma($ astaxanthin $) /(\mathrm{mg} / \mathrm{L})$ \\
\hline \multicolumn{6}{|c|}{ Rigor $(N=80)$} \\
\hline Pre & $1.9 \pm 0.9$ & $85.7 \pm 2.3$ & $0.03 \pm 0.01$ & $13.6 \pm 2.7$ & $0.15 \pm 0.04$ \\
\hline Post & $1.4 \pm 1.1$ & $86.4 \pm 1.3$ & $0.035 \pm 0.008$ & $12.6 \pm 1.4$ & $0.15 \pm 0.02$ \\
\hline$p$-value & $<0.001$ & 0.003 & $>0.05$ & 0.002 & $>0.05$ \\
\hline \multicolumn{6}{|c|}{ Season $(N=80)$} \\
\hline Spring & $1.8 \pm 1.1$ & $86.0 \pm 1.8$ & $0.03 \pm 0.01$ & $13.4 \pm 2.2$ & $0.1 \pm 0.03$ \\
\hline Autumn & $1.5 \pm 1.1$ & $86.1 \pm 2.2$ & $0.03 \pm 0.01$ & $12.8 \pm 2.2$ & $0.2 \pm 0.04$ \\
\hline$p$-value & $<0.001$ & $>0.05$ & $>0.05$ & 0.014 & $>0.05$ \\
\hline \multicolumn{6}{|c|}{ Localization $(N=80)$} \\
\hline South & $1.6 \pm 1.1$ & $85.8 \pm 1.9$ & $0.03 \pm 0.01$ & $13.2 \pm 2.2$ & $0.14 \pm 0.04$ \\
\hline North & $1.7 \pm 1.0$ & $86.3 \pm 2.2$ & $0.03 \pm 0.01$ & $13.0 \pm 2.3$ & $0.15 \pm 0.03$ \\
\hline$p$-value & $>0.05$ & 0.011 & $>0.05$ & $>0.05$ & $>0.05$ \\
\hline
\end{tabular}

The results are expressed as mean value \pm S.D., ranked by ANOVA (general linear model) 


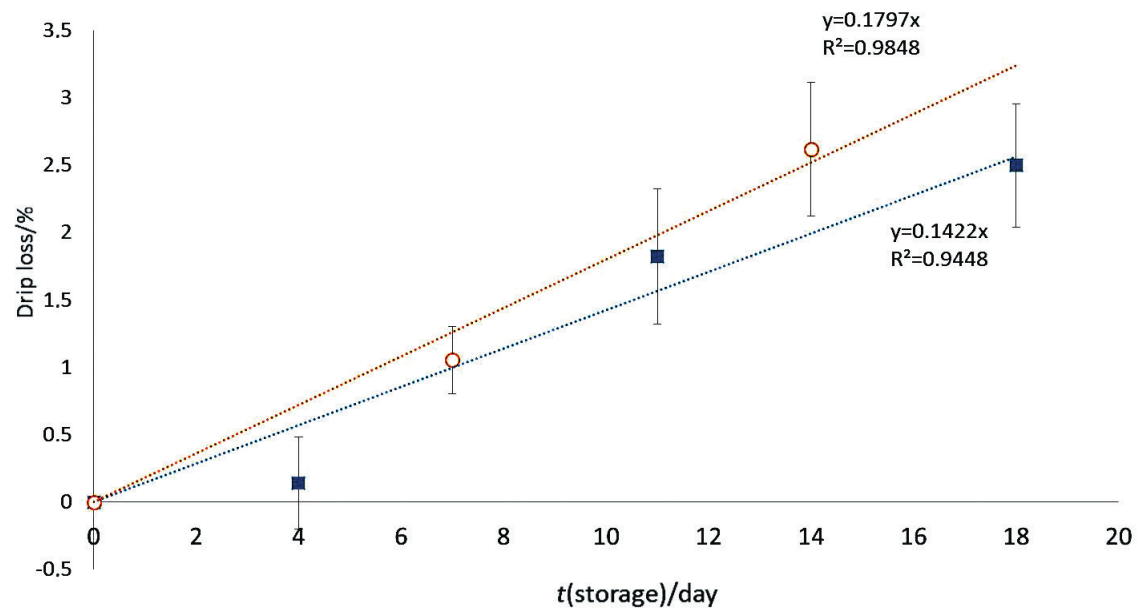

- Post rigor o Pre rigor

Fig. 4. Accumulated drip loss of pre-rigor (circle) and post-rigor (square) fillets stored on ice, where the post-rigor ones were stored as head on gutted for the first 4 days $(N=80)$

The water content was significantly higher in drip loss from post-rigor fillets ( $p=0.005, F=8.5)$, and in fillets from the north location ( $p=0.001, F=4.6$ ), while the protein content was significantly lower in post-rigor fillets $(\mathrm{p}=0.002, \mathrm{~F}=12)$ and in the fillets from the autumn group ( $p=0.014, F=5.6$ ). In addition, significant interaction effects between location and rigor status were found on both water content $(p<0.001, F=22)$ and protein content ( $p=0.003, F=11)$ (Fig. 5). Degradation of protein is an effect of autolysis, where the degradation increases with time. Proteins lost in the drip loss are the water-soluble proteins. The composition of proteins in salmon muscle varies during storage, and water-soluble proteins decrease significantly from 5 to 14 days post mortem (11). Post-rigor filleted salmon was 4 days older at the time of assessment than the

a)

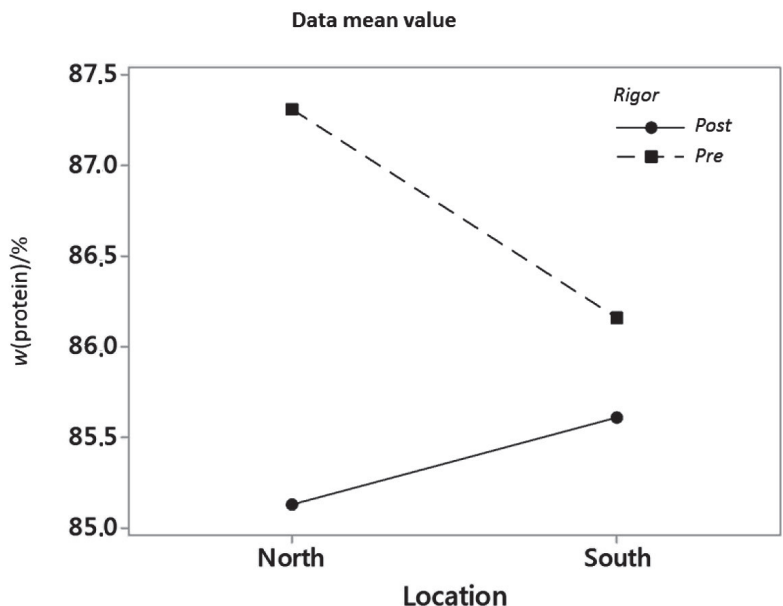

pre-rigor salmon, and this time difference can explain lower amount of protein in the drip loss. In farmed cod, pre-rigor fillets lost more protein than post-rigor fillets (35), most likely due to the same effect. In addition, the amount of protein increased during storage, confirming the degradation of the fillet.

\section{CONCLUSIONS}

All the investigated variables had impact on different quality aspects on the salmon, where rigor status and filleting had the highest impact on water-holding capacity and water content in the muscle. In addition, storage time was the factor that had the highest impact on the drip loss during storage.

b)

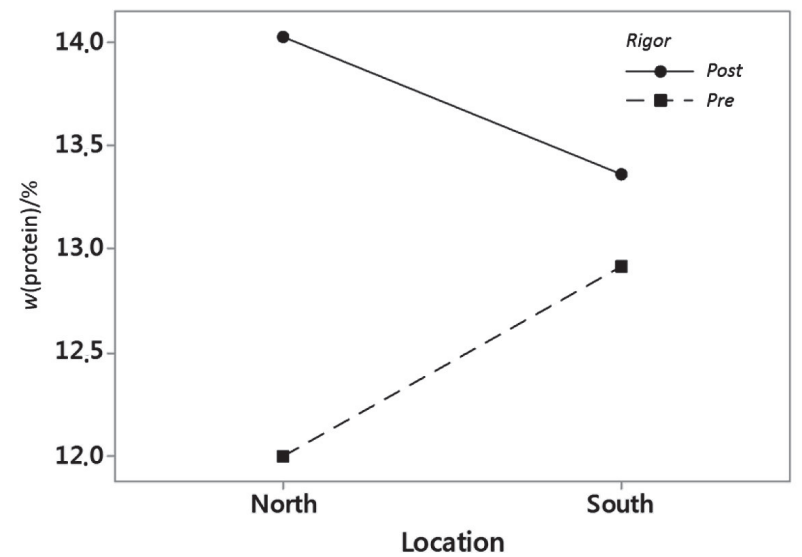

Fig. 5. Interaction plot between localization (north: N63-64, and south: N58-59 $)$ and rigor (pre and post) status for: a) water content in the drip loss $(p<0.001, F=22)$ and $b)$ protein content in the drip loss $(p=0.003, F=11)(N=80)$ 
Based on this trial, it is concluded that pre-rigor filleted salmon have excellent water-holding properties and a great potential for early processing (pre-rigor processing). It was however difficult to find a clear connection between the drip loss and the water-holding capacity of the muscle.

\section{ACKNOWLEDGEMENT}

The Norwegian Research Council (project 219209) supported this project financially. The Norwegian Research Council had no other role than financing the project. The authors want to thank staff at Nofima, Norwegian University of Science and Technology and Marine Harvest for excellent technical support.

\section{REFERENCES}

1. Fennema OR. Comparative water-holding properties of various muscle foods. J Muscle Foods. 1990;1 (4):363-81. https://doi.org/10.1111/j.1745-4573.1990.tb00373.x

2. Huff-Lonergan E, Lonergan SM. New frontiers in understanding drip loss in pork: Recent insights on the role of postmortem muscle biochemistry. J Anim Breed Genet. 2007; 124:19-26. https://doi.org/10.1111/j.1439-0388.2007.00683.x

3. Schäfer A, Rosenvold K, Purslow PP, Andersen HJ, Henckel P. Physiological and structural events post mortem of importance for drip loss in pork. Meat Sci. 2002;61(4):355-66. https://doi.org/10.1016/S0309-1740(01)00205-4

4. Huff-Lonergan E, Lonergan SM. Mechanisms of water-holding capacity of meat: The role of postmortem biochemical and structural changes. Meat Sci. 2005;71(1):194-204. https://doi.org/10.1016/j.meatsci.2005.04.022

5. Offer G, Cousins T. The mechanism of drip production: Formation of two compartments of extracellular space in muscle post mortem. J Sci Food Agr. 1992;58(1):107-16. https://doi.org/10.1002/jsfa.2740580118

6. Lerfall J, Roth B, Skare EF, Henriksen A, Betten T, Dziatkowiak-Stefaniak MA, Rotabakk BT. Pre-mortem stress and the subsequent effect on flesh quality of pre-rigor filleted Atlantic salmon (Salmo salar L.) during ice storage. Food Chem. 2015;175:157-65. https://doi.org/10.1016/j.foodchem.2014.11.111

7. Roth B, Slinde E, Arildsen J. Pre or post mortem muscle activity in Atlantic salmon (Salmo salar). The effect on rigor mortis and the physical properties of flesh. Aquaculture. 2006;257(1-4):504-10. https://doi.org/10.1016/j.aquaculture.2005.10.021

8. Mørkøre T, Mazo TPI, Tahirovic V, Einen O. Impact of starvation and handling stress on rigor development and quality of Atlantic salmon (Salmo salar L). Aquaculture. 2008;277(3-4):231-8. https://doi.org/10.1016/j.aquaculture.2008.02.036

9. Ofstad R, Kidman S, Myklebust R, Olsen RL, Hermansson AM. Liquid-holding capacity and structural changes in comminuted salmon (Salmo salar) muscle as influenced by $\mathrm{pH}$, salt and temperature. LWT - Food Sci Technol. 1995;28(3):329-39.

https://doi.org/10.1016/S0023-6438(95)94599-7

10. Ofstad R, Egelandsdal B, Kidman S, Myklebust R, Olsen RL, Hermansson AM. Liquid loss as effected by post mortem ultrastructural changes in fish muscle: Cod (Gadus morhua L) and salmon (Salmo salar). J Sci Food Agr. 1996;71(3):301-12. https://doi.org/10.1016/S0023-6438(95)94599-7

11. Hultmann L, Rustad T. Textural changes during iced storage of salmon (Salmo salar) and cod (Gadus morhua). J Aquat Food Prod Technol. 2002;11(3-4):105-23. https://doi.org/10.1300/J030v11n03_09

12. Mørkøre T, Rødbotten M, Vogt G, Fjžra SO, Kristiansen $І \varnothing$, Manseth E. Relevance of season and nucleotide catabolism on changes in fillet quality during chilled storage of raw Atlantic salmon (salmo salar L.). Food Chem. 2010;119(4):1417-25.

https://doi.org/10.1016/j.foodchem.2009.09.022

13. Fulton TW. The rate of growth of fishes. Twenty-second Annual Report, Part III. Edinburgh, Scotland, UK: Fisheries Board of Scotland; 1904. pp. 141-241.

14. ISO 6496:1999. Animal feeding stuffs - Determination of moisture and other volatile matter content. Geneva, Switzerland: International Organisation for Standardisation (ISO); 1999.

15. Skipnes D, Østby ML, Hendrickx ME. A method for characterising cook loss and water-holding capacity in heat treated cod (Gadus morhua) muscle. J Food Eng. 2007;80(4):1078-85. https://doi.org/10.1016/j.jfoodeng.2006.08.015

16. Nitrogen. Determination in foods and feeds according to Kjeldahl; No 6. Oslo, Norway: Nordic Committee on Food Analysis (NMKL); 2003.

17. Bligh EG, Dyer WJ. A rapid method of total lipid extraction and purification. Can J Biochem Phys 1959;37:911-7. https://doi.org/10.1139/059-099

18. Vecchi M, Glinz E, Meduna V, Schiedt K. HPLC separation and determination of astacene, semiastacene, astaxanthin, and other keto-carotenoids, J High Resol Cromatogr. $1987 ; 10(6) ; 348-51$

https://doi.org/10.1002/jhrc.1240100606

19. Schüep W, Schierle J. Astaxanthin. In: Britton G, Liaaen-Jensen S, Pfander H, editors. Carotenoids, vol. 1A: Isolation and analysis. Basel, Switzerland; Birkhäusen Verlag AG; 1995. pp. 273-6.

20. Minitab statistical software, v. 17, Minitab Ltd, Coventry, UK; 2014. Available from: http://www.minitab.com.

21. Jørpeland G, Imsland A, Stien LH, Bleie H, Roth B. Effects of filleting method, stress, storage and season on the quality of farmed Atlantic cod (Gadus morhua L.). Aquacult Res. 2013:46(7):1597-607.

https://doi.org/10.1111/are.12312 
22. Skjervold PO, Rørå AMB, Fjžra SO, Vegusdal A, Vorre A, Einen O. Effects of pre-, in-, or post-rigor filleting of live chilled Atlantic salmon. Aquaculture. 2001;194(3-4):315-26. https://doi.org/10.1016/S0044-8486(00)00531-7

23. Veiseth-Kent E, Hildrum KI, Ofstad R, Rørå MB, Lea P, Rødbotten $M$. The effect of postmortem processing treatments on quality attributes of raw Atlantic salmon (Salmo salar) measured by sensory and instrumental methods. Food Chem. 2010;121(1):275-81. https://doi.org/10.1016/j.foodchem.2009.12.009

24. Regenstein JM, Stamm RS. A comparison of the water-holding capacity of pre- and post-rigor chicken, trout and lobster muscle in the presence of polyphosphates and divalent cations. J Food Biochem. 1980;3(4):223-8. https://doi.org/10.1111/j.1745-4514.1980.tb00778.x

25. Einen O, Guerin T, Fjaera SO, Skjervold PO. Freezing of pre-rigor fillets of Atlantic salmon. Aquaculture. 2002;212(14):129-40. https://doi.org/10.1016/S0044-8486(01)00874-2

26. den Hertog-Meischke MJA, van Laack RJLM, Smulders FJM. The water-holding capacity of fresh meat. Vet $Q$. 1997;19(4):175-81. https://doi.org/10.1080/01652176.1997.9694767

27. Puolanne $E$, Halonen M. Theoretical aspects of water-holding in meat. Meat Sci. 2010;86(1):151-65. https://doi.org/10.1016/j.meatsci.2010.04.038

28. Sutton SG, Bult TP, Haedrich RL. Relationships among fat weight, body weight, water weight, and condition factors in wild Atlantic salmon parr. Trans Am Fish Soc. 2000;129(2):527-38.

https://doi.org/10.1577/1548-8659(2000)129<0527:RAFWBW $>2.0 . C O ; 2$

29. Roth B, Slinde E, Robb DHF. Field evaluation of live chilling with $\mathrm{CO} 2$ on stunning Atlantic salmon (Salmo salar) and the subsequent effect on quality. Aquacult Res. 2006;37(8):799804.

https://doi.org/10.1111/j.1365-2109.2006.01495.x

30. Nordgarden U, Oppedal F, Taranger GL, Hemre GI, Hansen T. Seasonally changing metabolism in Atlantic salmon (Salmo salar L) I - Growth and feed conversion ratio. Aquacult Nutr. 2003;9(5):287-93.

https://doi.org/10.1046/j.1365-2095.2003.00256.x

31. Handeland SO, Imsland AK, Stefansson SO. The effect of temperature and fish size on growth, feed intake, food conversion efficiency and stomach evacuation rate of Atlantic salmon post-smolts. Aquaculture. 2008;283(1-4):36-42. https://doi.org/10.1016/j.aquaculture.2008.06.042

32. Roth B, Imsland A, Stien LH, Schelvis-Smit R, Gunnarsson $S$, Foss $A$. The influence of anaerobic muscle activity, maturation and season on the flesh quality of farmed turbot. Aquacult Int. 2010;18(3):461-74. https://doi.org/10.1007/s10499-009-9257-3

33. Skjervold PO, Fjaera SO, Østby PB, Isaksson T, Einen O, TayIor R. Properties of salmon flesh from different locations on pre- and post-rigor fillets. Aquaculture. 2001;201(1-2):91106.

https://doi.org/10.1016/S0044-8486(01)00556-7

34. Rosnes JT, Vorre A, Folkvord L, Hovda M, Fjžra SO, Skjervold PO. Effects of pre-, in-, and post-rigor filleted Atlantic salmon (Salmo salar) on microbial spoilage and quality characteristics during chilled storage. J Aquat Food Prod Technol. 2003;12(2):17-31. https://doi.org/10.1300/J030v12n02_03

35. Kristoffersen S, Vang B, Larsen R, Olsen RL. Pre-rigor filleting and drip loss from fillets of farmed Atlantic cod (Gadus morhua L). Aquacult Res. 2007;38(16):1721-31. https://doi.org/10.1111/j.1365-2109.2007.01843.x 